\section{La educación médica en Latinoamérica}

Arcadi Gual

\section{Medical education in Latin America}

La salud de la educación médica, entendida como un área de conocimiento, ha ido creciendo poco a poco en todo el mundo hasta llegar a la situación actual, en la que debemos reconocer, sin ambages de ningún tipo, su mayoría de edad. Ciertamente, las comparaciones son odiosas, de modo que esta madurez no es de igual calado si comparamos unas áreas geográficas, o quizás mejor unas áreas culturales, respecto de otras. La cultura anglosajona, quizá por su tradición de modelo educativo muy centrado en el alumno, lleva de largo la delantera pero también es cierto el progresivo afianzamiento y mejora de otras áreas o territorios.

Hoy, porque es de justicia, queremos poner de relieve la solidez de la educación médica en el área latinoamericana. Su presencia en los congresos nacionales e internacionales muestra una línea ascendente, y un buen signo de esta solidez es la importante presencia en esta publicación, Educación Médica, de artículos originales procedentes del continente americano. Por otro lado, en los congresos de la AMEE, el más importante congreso mundial sobre educación médica, el Iberoamerican Group, se ha consolidado como un referente.

Posiblemente, una de las estructuras que han ayudado a la consolidación de la educación médica en las Américas ha sido la Federación Panamericana de Asociaciones de Facultades y Escuelas de Medicina (FEPAFEM/PAFAMS) que, de manos de sus actuales presidente y director ejecutivo, Dr. L. N. Ferreira y Dr. P. A. Pulido, han aunado esfuerzos para encontrar las mejores
In recent years, medical education, as an area of knowledge, has enjoyed increasingly better health all over the world until reaching the current situation, where we can state without a shadow of a doubt that it has finally come of age. It is true that comparisons are odious and if we look at different geographical or, perhaps better still, cultural areas, it becomes clear that it has not achieved the same degree of maturity across the board. Perhaps due to their traditional model of education that focuses very strongly on the pupil, English-speaking societies lead the field by far, but it is also true that medical education is gradually improving and becoming progressively more firmly established in other areas or territories.

Thus, today it is only fair to highlight the sturdiness of medical education in the area of Latin America. It is increasingly more commonly present at national and international conferences and a clear sign of this consolidation is the important number of original papers published in this journal, Educación Médica, that come from the American continent. Moreover, the Ibero-American Group has now become a reference at AMEE conferences, the most important conference in the world on medical education.

Perhaps one of the structures that have helped to consolidate medical education in America has been the Pan-American Federation of Associations of Medical Schools (FEPAFEM/PAFAMS), which, under the guidance of its current Chairman and Executive Director Dr L.N. Ferreira and Dr P.A. Pulido, have joined forces to find the best
Director de la Fundación Educación Médica

E-mail agual@ub.edu 
vías de cooperación entre los diferentes países que la componen.

FEPAFEM (www.fepafempafams.org) fue constituida en 1962 en Viña del Mar (Chile) como una institución interamericana de naturaleza académica y científica, cuyo propósito es contribuir al perfeccionamiento de la educación médica en la Américas. Está integrada por 13 asociaciones nacionales de facultades de medicina del continente americano y por 8 facultades individualmente afiliadas, así como por diversos miembros asociados. Hoy, al igual que ya lo venían haciendo otros organismos internacionales relacionados con la educación médica, FEPAFEM se suma a la lista de auspiciadores de esta revista, Educación Médica. Nosotros nos sentimos orgullosos de esta circunstancia y consideramos que su presencia en nuestras páginas prestigia esta revista y aumenta nuestro compromiso de ofrecer al mundo iberoamericano interesado en la educación médica el mejor de los productos posibles. Esperamos no sólo no defraudarles sino mejorar, dentro de nuestras posibilidades, los intercambios, la difusión y la cooperación entre todos los profesionales que viven y sienten suyo este mundo: la educación médica. ways for the member countries to cooperate with one another.

The FEPAFEM (www.fepafempafams.org) was set up in 1962 in Viña del Mar (Chile) as an inter American academic and scientific institution, whose purpose is to help to improve medical education in the Americas. It consists of 13 national associations of medical schools from the American continent and 8 individually affiliated faculties, as well as a number of associated members. Today, following the steps of other international bodies related with medical education, FEPAFEM has now added its name to the list of sponsors of this journal, Educación Médica. We are proud of this fact and consider that having it as a contributor to our publication can only improve the reputation of this journal. At the same time it also drives us to step up our commitment to offer the best possible products to those living in Latin America who share an interest in medical education. We hope they are not going to be disappointed, and we also aim to do everything we can to encourage and improve exchange, diffusion and cooperation among all those professionals who have centred their careers and lives on medical education. 